\title{
Analisis Faktor-Faktor Yang Mempengaruhi Fraud Pengadaan Barang Dan Jasa Di Pemerintahan Desa
}

\author{
Ni Kadek Indah Permata Sari ${ }^{1}$ \\ Fakultas Ekonomi dan Bisnis \\ Universitas Udayana, Indonesia \\ Email: indahkadek03@gmail.com
}

\author{
I Wayan Suartana ${ }^{2}$ \\ Fakultas Ekonomi dan Bisnis \\ Universitas Udayana, Indonesia
}

\begin{abstract}
ABSTRAK
Upaya memajukan desa terlihat dari bantuan desa yang ditingkatkan setiap tahunnya dengan sistem tata kelola yang tepat. Namun pengelolaan keuangan Desa yang belum optimal menyebabkan timbulnya fraud dalam bidang pengadaan barang dan jasa. Penelitian ini bertujuan untuk menguji pengaruh kualitas panitia pengadaan, etika pengadaan, kompensasi panitia pengadaan, sistem dan prosedur pengadaan serta lingkungan pengadaan terhadap fraud pengadaan barang dan jasa di Pemerintahan Desa. Penelitian berlokasi di Kabupaten Badung. Responden berjumlah 60 orang. Teknik analisis data menggunakan analisis regresi linier berganda. Hasil Penelitian ini menunjukan bahwa kualitas panitia pengadaan, etika pengadaan, sistem dan prosedur pengadaan berpengaruh negatif, namun kompensasi panitia pengadaan dan lingkungan pengadaan tidak berpengaruh terhadap fraud pengadaan barang dan jasa di Pemerintahan Desa.
\end{abstract}

Kata Kunci: Etika dan Lingkungan Pengadaan; Kompensasi Panitia Pengadaan; Sistem dan Prosedur Pengadaan, Fraud.

\section{Factors Affecting Fraud In Procurement Of Goods And Services In Village Government}

\begin{abstract}
Advancing villages can be seen from the existence of village assistance which is increased every year and followed by an appropriate governance system in accordance with regulations or laws. However, village financial management that has not been optimal causes fraud in the field of procurement of goods and services. This study aims to examine the effect of the quality of the procurement committee, procurement ethics, procurement committee compensation, procurement systems and procedures as well as the procurement environment on fraud procurement of goods and services. The research conducted in Badung . 60 people used as respondents. Data analysis techniques used multiple linear regression. The quality of the procurement committee, procurement ethics, procurement systems and procedures have negative effect, but the compensation of the procurement committee and the procurement environment does not affect the procurement of goods and services fraud.
\end{abstract}

Keywords: $\quad$ Ethics and Procurement Environment, Procurement Committee Compensation, Procurement Systems and Procedures, Fraud.

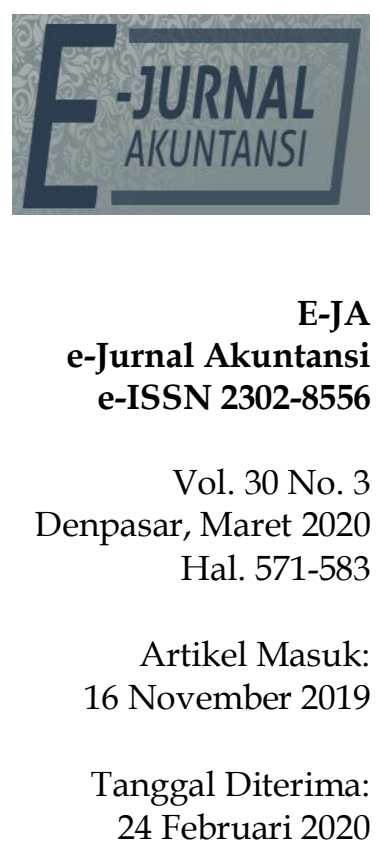

24 Februari 2020 


\section{PENDAHULUAN}

Keseriusan Pemerintah Indonesia memajukan desa terlihat dari adanya bantuan desa yang ditingkatkan setiap tahunnya serta diikuti dengan sistem tata kelola yang tepat sesuai dengan regulasi atau aturan perundang-undangan. Peraturan yang kini berlaku adalah Undang-Undang Nomor 6 tahun 2014 tentang Desa, dimana pemerintah Desa memperoleh dana yang relatif besar untuk dikelola atau dipertanggungjawabkan dengan tepat (Roden et al., 2016). Selain itu, pemerintah juga telah mempersiapkan beberapa peraturan lain untuk mendukung akuntabilitas dana desa tersebut (Meutia \& Liliana, 2017). Pemerintah memberikan bantuan langsung berupa dana desa yang menjadi wujud nyata dalam upaya mengembangkan desa dengan mendukung perbaikan infrastruktur fisik maupun non fisik desa (Tibuludji, 2017). Dana desa yang relatif besar diharapkan dapat membawa perubahan baru dalam pembangunan (Atmadja \& Saputra, 2017)

Program dana desa bertujuan untuk mewujudkan pertumbuhan ekonomi dan pemerataan pendapatan dengan prioritas untuk membiayai pengembangan dan pemberdayaan masyarakat, (Yunita \& Christianingrum, 2019). Dana Desa mewajibkan Pemerintah Desa mengelola dana yang ada dengan akuntabel dan transparan sesuai dengan aturan yang berlaku agar tidak terjadi tindakan penyelewengan dana desa (Santi Putri Laksmi \& Sujana, 2019). Pemerintah desa yang akuntabel dan transaparan dilihat dari kinerja serta tanggung jawabnya dalam mengelola keuangan desa. Hal ini menyebabkan anggaran dana desa yang besar harus berbanding lurus dengan kompetensi yang dimiliki oleh aparatur desa, khususnya Kepala Desa (Sholihat et al., 2017). Abidin (2015) menyatakan bahwa permasalahan tentang pengelolaan keuangan desa bersumber dari rendahnya SDM aparatur desa khususnya dalam pengetahuan tata kelola dan pelaporan keuangan sehingga berpotensi terjadi tindakan fraud (kecurangan).

Dalam pengelolaan keuangan desa terdapat poin penting untuk mendapatkan perhatian yang serius yaitu pengadaan barang dan jasa, karena dalam hal pengadaan barang dan jasa terdapat banyak ruang dan celah terjadinya berbagai bentuk fraud yang disebabkan oleh rendahnya sumber daya manusia yang ada di desa. Kecurangan (fraud) merupakan perbuatan yang dilakukan oleh seseorang atau berkelompok yang melanggar hukum, hal tersebut bisa disengaja maupun tidak disengaja dengan tujuan memperoleh keuntungan berupa uang, aset dan lainnnya serta merugikan orang lain atau pihak tertentu (Aini et al., 2017). Kecurangan (fraud) dapat berupa Mark up, suap dan fiktif. Tindakan Mark up dapat berupa penggelembungan harga, suap dapat berupa penyogokan agar penyedia tersebut dipilih untuk menyediakan barang yang dibutuhkan desa, fiktif dapat berupa anggaran sudah dikeluarkan tetapi barang yang diadakan atau dibeli tidak ada.

Perlu diketahui di sektor pemerintahan dugaan fraud dapat dilihat dari kegiatan yang tidak terlaksana, misalnya proyek yang tidak diteruskan, peralatan yang sudah dibeli namun tidak berfungsi dengan baik, pengadaan barang/ jasa tidak dianggarkan dengan tepat, robohnya bangunan gedung akibat umur konstruksi yang singkat, perbedaan harga perkiraan sendiri (HPS) barang sejenis yang cukup mencolok antara satu instansi dengan instansi lain. 
Kejadian diatas menunjukkan pihak pengelola keuangan desa cenderung kurang paham tentang cost awareness (kesadaran atas uang publik) sehingga harus dilakukan perbaikan dengan langkah-langkah konkret dan membangun kesadaran ini tidak hanya bagi aparat desa tapi juga masyarakat pada umumnya, sehingga pengawasan terhadap pengelolaan keuangan desa seharusnya dilakukan secara profesional, ketat, terkontrol dan berintegritas (Galih Prasetyo et al., 2015).

Terjadinya tindakan fraud tidak lepas dari berbagai aspek yaitu kurang kompetennya tim pengelola, rendahnya integritas dan indepedensi panitia pengadaan itu sendiri (Thorburn \& Kull, 2015). Guna mencegah terjadinya pelanggaran tersebut, maka panitia pengadaan dituntut untuk memiliki tiga komponen diatas, yaitu: profesionalitas, integritas dan independensi yang tinggi, sebab banyaknya tindakan fraud terjadi akibat tidak memperhatikan ketiga komponen tersebut. Selain ketiga komponen itu, panitia pengadaan harus mengerti regulasi tentang pengadaan barang dan jasa. Regulasi inilah yang menjadi pedoman bagi panitia pengadaan dalam melakukan pengadaan barang/jasa, sehingga tercipta pengadaan yang sehat dan tepat sasaran (Usuro \& Adigwe, 2015).

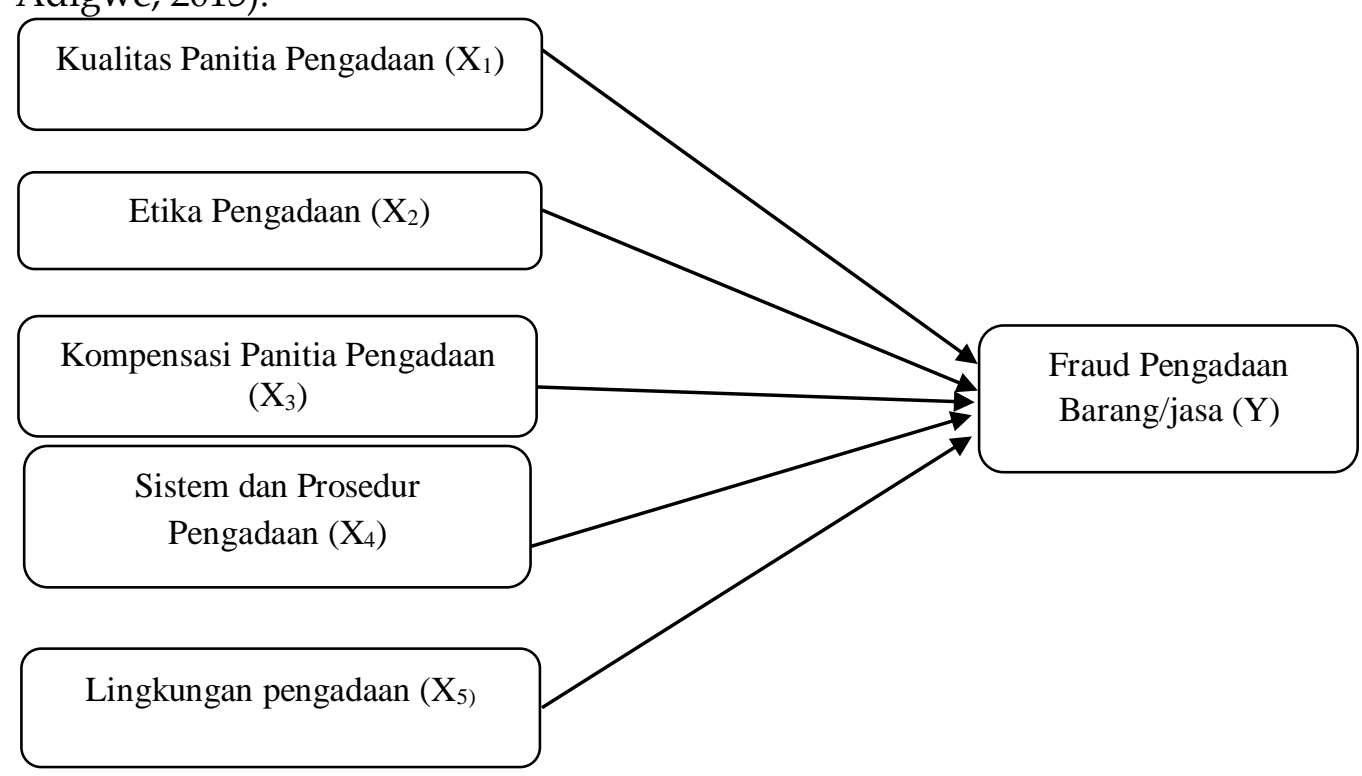

Sumber: Data Penelitian, 2019

\section{Gambar 1. Kerangka Konseptual}

Teori keagenan berasumsi bahwa, principal menginginkan institusi dikelola sebaik-baiknya oleh agen, meskipun terdapat perbedaan kepentingan antara principal dan agen, namun principal sangat mengharapkan seorang agen yang berkualitas dan berpengalaman (Panda \& Leepsa, 2017). Seorang agen yang berkualitas, adalah agen yang memiliki integritas, kompetensi, indepedensi dan obyektifitas sehingga institusi dapat mengelola organisasinya untuk mencegah fraud, serta profesionalisme atau kualitas panitia pengadaan salah satu faktor yang ikut mempengaruhi keberhasilan suatu sistem pengadaan dalam mencapai tujuan yang telah ditetapkan (Pratama et al., 2017)

Penelitian yang dilakukan Yanavia (2014) terkait kualitas panitia pengadaan, dalam penelitiannya kualitas panitia pengadaan memberikan pengaruh terhadap 
pelaksanaan pengadaan barang dan jasa, penelitian ini selajan dengan Penelitian yang dilakukan Nisa Nurharjanti (2017) \& Hidayati et al. (2017) yang menunjukkan bahwa variabel kualitas panitia pengadaan berpengaruh negatif terhadap fraud pengadaan barang/jasa. Semakin tinggi kualitas panitia pengadaan (integritas, kompetensi, indepedensi, obyektifitas) maka akan semakin rendah panitia melakukan fraud. Mengacu pada uraian tersebut, dirumuskan hipotesis sebagai berikut:

$\mathrm{H}_{1}$ : Terdapat pengaruh negatif dari kualitas panitia pengadaan terhadap fraud pengadaan barang dan jasa di pemerintahan desa.

Dalam teori keagenan, principal menginginkan agar agen melakukan pekerjaannya dengan baik sesuai dengan kontrak kerja dan etika yang berlaku demi keuntungan institusi serta penerapan etika dalam pekerjaan merupakan hal yang penting bagi agen untuk melaksanakan pekerjaannya. Etika adalah normanorma, kaidah-kaidah dan nilai-nilai moral yang berlaku (Pepper \& Gore, 2015). Penerapan etika dalam proses pengadaan barang dan jasa dapat mencegah terjadinya fraud. Dalam Perbup Badung No. 40 Tahun 2014 tentang tata cara pengadaan barang dan jasa desa terdapat tentang etika dalam pengadaan barang dan jasa yaitu bertanggung jawab, mencegah kebocoran, dan pemborosan keuangan desa serta patuh terhadap peraturan perundang-undangan merupakan aspek penting yang terdapat dalam Perbup Badung No. 40 Tahun 2014 tentang tata cara pengadaan barang dan jasa. Etika Pengadaan sebagai faktor yang berpengaruh terhadap fraud pengadaan barang dan jasa didasarkan atas penelitian yang dilakukan oleh Yanavia (2014) membuktikan bahwa faktor etika pengadaan sangat dominan untuk mendorong terjadinya fraud pengadaan barang dan jasa. Penelitian ini sejalan dengan Hidayati et al. (2017), Zitha \& Mathebula (2015), Mazibuko \& Fourie (2017), Ilham et al. (2017), Gorsira et al., (2018), Said et al., (2017), Ambe \& Badenhorst-Weiss (2015) dan Gol \& Moronge (2017) yaitu etika berpengaruh negatif terhadap fraud pengadaan barang/ jasa. Penelitian ini diyakini bahwa semakin baik etika dalam proses pengadaan barang dan jasa maka akan semakin rendah tingkat fraud. Berdasarkan uraian diatas maka dirumuskan hipotesis sebagai berikut:

$\mathrm{H}_{2}$ : Terdapat pengaruh negatif dari etika pengadaan terhadap fraud pengadaan barang dan jasa di pemerintahan desa.

Dalam organisasi, principal memiliki kewajiban untuk memberikan imbalan atas pekerjaan yang dilakukan oleh agen. Imbalan yang sesuai dengan kewajiban adalah hal yang paling dibutuhkan untuk mencegah terjadinya fraud. Kompensasi pengadaan barang dan jasa adalah salah satu faktor utama yang dapat memotivasi agen untuk melakukan pekerjaannya secara baik atau tidak baik dan faktor kompensasi panitia pengadaan dapat mendorong terjadinya fraud pengadaan barang dan jasa (Yanavia, 2014). Hal ini didukung juga oleh penelitian yang dilakukan oleh Adinda (2015) yang membuktikan bahwa kompensasi panitia pengadaan berpengaruh terhadap terjadinya fraud pengadaan barang dan jasa, sehingga seseorang yang terpuaskan kompensasinya tidak akan melakukan reaksi kompromistis dalam bentuk tindakan kecurangan. Pembuktian kembali faktor kompensasi pengadaan barang dan jasa sebagai salah satu faktor yang berpengaruh terhadap fraud pengadaan barang dan jasa perlu dilakukan kembali, hal ini disebabkan oleh penelitian terdahulu seperti Arifianti 
et al. (2016) menyatakan bahwa kesesuaian kompensasi tidak berpengaruh terhadap fraud pengadaan barang dan jasa. Berdasarkan uraian diatas maka dirumuskan hipotesis berikut :

$\mathrm{H}_{3}$ : Terdapat pengaruh negatif dari kompensasi panitia pengadaan terhadap fraud pengadaan barang dan jasa di pemerintahan desa.

Teori keagenan berasumsi bahwa dalam organisasi, principal memberikan mandat kepada agen untuk melaksanakan pekerjaannya atas nama principal. Agen memiliki tugas dan kewenangan dalam proses pelaksanaan maupun perencanaan suatu pekerjaan yang diberikan oleh principal. Dalam melaksanakan tugasnya, agen harus mengikuti prosedur yang ada agar pekerjaannya berlangsung lancar dan dapat mencegah fraud (Yanavia, 2014).

Sistem dan prosedur pengadaan dijadikan faktor yang mempengaruhi terjadinya fraud didasarkan pada penelitian yang dilakukan Nisa Nurharjanti (2017) yang membuktikan bahwa sistem dan prosedur pengadaan berpengaruh terhadap terjadinya fraud pengadaan barang dan jasa. Penelitian lain yakni Yanavia (2014) membuktikan bahwa sistem dan prosedur pengadaan barang dan jasa dapat mendorong terjadinya fraud pengadaan barang dan jasa. Penelitian tersebut sejalan dengan Hidayati et al. (2017) sistem dan prosedur pengadaan berpengaruh secara negatif terhadap fraud pengadaan barang/jasa, jika proses pengadaan barang dan jasa tidak dilakukan dengan sistem dan prosedur pengadaan, maka hal ini akan dapat mendorong terjadinya fraud pengadaan barang dan jasa. Mengacu pada uraian diatas dapat dirumuskan hipotesis sebagai berikut:

$\mathrm{H}_{4}$ : Terdapat pengaruh negatif dari sistem dan prosedur pengadaan terhadap fraud pengadaan barang dan jasa di pemerintahan desa.

Teori keagenan berasumsi bahwa adanya konflik antara principal dan agen salah satunya adalah karena kepentingan yang saling bertentangan (conflict of interest) dan lingkungan yang buruk juga dapat menyebabkan terjadinya fraud Sistem dan prosedur pengadaan akan selalu berinteraksi dengan lingkungan dimana sistem tersebut diterapkan, lingkungan merupakan salah satu tfaktor yang tmempengaruhi tkemampuan tsuatu tsistem tpengadaan tbarang/jasa tuntuk mencapai ttujuan tyang ttelah tditetapkan. Aspek lingkungan meliputi lingkungan internal maupun eksternal. Lingkungan internal dalam pengadaan barang/jasa pemerintah adalah kondisi lingkungan kerja yang baik. (Yanavia, 2014).

Penelitian yang dilakukan Yanavia (2014) membuktikan bahwa lingkungan pengadaan dapat mendorong terjadinya fraud pengadaan barang dan jasa, sejalan dengan penelitian Nisa Nurharjanti (2017) melalui hasil penelitiannya membuktikan bahwa lingkungan pengadaan berpengaruh signifikan terhadap terjadinya fraud pengadaan, penelitian ini diyakini bahwa semakin baik lingkungan pengadaan maka semakin baik dan lancar proses pengadaannya. Hal ini menjadi dasar dirumuskannya hipotesis sebagai berikut:

$\mathrm{H}_{5}$ : Terdapat pengaruh negatif dari lingkungan pengadaan terhadap fraud pengadaan barang dan jasa di pemerintahan desa. 


\section{METODE PENELITIAN}

Penelitian ini menggunakan pendekatan kuantitatif yang bersifat asosiatif. Penelitian ini dilakukan di beberapa Kantor Desa yang ada di Kabupaten Badung. Obyek penelitian yang digunakan dalam penelitian ini adalah fraud pengadaan barang dan jasa Pemerintahan Desa di Kabupaten Badung. Variabel terikat dalam penelitian ini adalah fraud pengadaan barang dan Jasa. Variabel bebas dalam penelitian ini adalah: kualitas panitia pengadaan, etika pengadaan, kompensasi panitia pengadaan, sistem dan prosedur pengadaan, lingkungan pengadaan.

Populasi dalam penelitian ini adalah Tim Pengelola Kegiatan Pengadaan Barang/Jasa Desa yang berasal dari unsur Pemerintah Desa dan unsur Lembaga Kemasyarakatan Desa yaitu Ketua Tim Pengelola Kegiatan, Sekertaris Tim Pengelola Kegiatan dan anggota Tim Pengelola Kegiatan. Setiap desa dalam pengadaan barang/jasa harus memiliki 3 orang penyelenggara kegiatan yang berkedudukan di 46 desa se Kabupaten Badung. Sehingga populasi yang didapat sebesar $46 \times 3$ responden $=138$ sampel.

Pengambilan sampel dalam penelitian ini dengan teknik probability sampling dengan proportionate stratified random sampling dengan menggunakan rumus Slovin. Dalam penelitian ini mengumpulkan data dengan menggunakan kuesioner (instrument) dan Obersevasi. Data yang digunakan dalam penelitian ini adalah berita dalam harian Koran Bali Post tentang kasus fraud di kabupaten Badung serta data tentang identitas responden penelitian. Data kuantitatif dalam penelitian ini adalah jawaban responden. Data primer didapatkan dari jawaban responden mengenai pertanyaan kuesioner yang disebarkan di beberapa desa yang mendapatkan Dana Desa khususnya di Kabupaten Badung. Data sekunder dalam penelitian ini yaitu data yang diperoleh dari Bali Post surat kabar harian ibu kota Provinsi Bali di Jalan Kepundung Denpasar dan Peraturan Bupati badung tentang pembagian dana desa.

\section{HASIL DAN PEMBAHASAN}

Responden yang berusia 20-35 tahun berjumlah 18 orang (30,00 persen), responden yang berusia $36-50$ tahun berjumlah 27 orang (45,00 persen), dan responden diatas 50 tahun berjumlah 15 orang (25 persen), maka dapat disimpulkan bahwa sebagian besar responden pada Kantor Perbekel di Kabupaten Badung berusia 36-50 tahun. responden yang berjenis kelamin laki laki berjumlah 42 orang (70,00 persen) dan perempuan berjumlah 18 orang $(30,00$ persen), maka dapat disimpulkan bahwa sebagian besar responden pada Kantor Perbekel di Kabupaten Badung berjenis kelamin laki-laki.

Responden yang berlatar pendidikan SMA/SMK/STM berjumlah 12 orang (20,00 persen), Diploma berjumlah 6 orang (10,00 persen) dan S1 berjumlah 42 orang (70,00 persen), maka dapat disimpulkan mayoritas responden pada Kantor Perbekel di Kabupaten Badung berlatar belakang pendidikan S1 (Strata 1). Responden yang lama bekerja 1-5 tahun berjumlah 21 orang ( 35,00 persen), lama bekerja 6-10 tahun berjumlah 24 orang $(40,00$ persen) dan lama bekerja diata 10 tahun berjumlah 15 orang (25,00 persen), maka dapat disimpulkan bahwa responden pada Kantor Perbekel di Kabupaten Badung yang sebagian besar bekerja antara 6-10 tahun. 
Nilai dari Adjusted $R$ Square adalah 0,418 atau 41,8 persen, ini artinya variasi fraud dipengaruhi oleh kualitas panitia pengadaan, etika pengadaan, kompensasi panitia pengadaan, sistem dan prosedur pengadaan dan lingkungan pengadaan, sisanya dijelaskan oleh variabel-variabel yang tidak dijelaskan dalam penelitian ini. Nilai signifikansi uji $\mathrm{F}$ yaitu sebesar 0,000 lebih kecil dari 5 persen $(0,000<0,005)$. Ini berarti model yang digunakan pada penelitian ini layak. Hasil ini memberikan makna bahwa seluruh variabel independen yang terdiri dari kualitas panitia pengadaan, etika pengadaan, kompensasi panitia pengadaan, sistem dan prosedur pengadaan serta lingkungan pengadaan mampu menjelaskan dan mempredeksi fraud pengadaan barang dan jasa, dengan kata lain ada pengaruh secara simultan.

Tabel 1. Hasil Analisis Regresi Linier Berganda

\begin{tabular}{lllll}
\hline Variabel & $\begin{array}{l}\text { Unstandardiced } \\
\text { Beta }\end{array}$ & Std Error & T hitung & Sig uji t \\
\hline Constant & 54.531 & 6.865 & 7.943 & 0.000 \\
Kualitas Panitia (X1) & -0.734 & 0.163 & -4.508 & 0.000 \\
Etika (X2) & -0.432 & 0.207 & -2.081 & 0.042 \\
Kompensasi (X3) & -0.021 & 0.271 & -0.078 & 0.938 \\
Sistem dan Prosedur & -0.506 & 0.222 & -2.278 & 0.027 \\
(X4) & -0.020 & 0.297 & -0.066 & 0.948 \\
\hline Lingkungan (X4) & & & &
\end{tabular}

Sumber: Data Penelitian, 2019

Agency Theory berkaitan dengan kualitas panitia pengadaan yaitu dimana principal (masyarakat desa) menginginkan organisasi dikelola sebaik-baiknya oleh agen (perangkat desa), meskipun terdapat perbedaan kepentingan antara principal dan agen, namun principal sangat mengharapkan seorang agen yang berkualitas dan berpengalaman. Seorang agen yang berkualitas adalah agen yang memiliki integritas, kompetensi, indepedensi dan obyektifitas untuk melaksanakan pengadaan barang dan jasa desa sehingga agen dapat mengelola organisasinya dengan tepat untuk mencegah terjadinya fraud. Hipotesis pertama pada penelitian ini menyatakan bahwa kualitas panitia pengadaan berpengaruh negatif terhadap fraud pengadaan barang dan jasa di Pemerintahan Desa. Hasil pengujian dengan menggunakan regresi linier berganda sejalan dengan hipotesis yang dirumuskan yang menunjukan bahwa kualitas panitia pengadaan berpengaruh negatif terhadap fraud. Nilai regresi menunjukan nilai koefisien negatif sebesar 0,734 dengan nilai signifikansi sebesar 0,000 yang lebih kecil dari $\alpha=0,05(0,000<0,05)$. Hasil ini memiliki arti bahwa semakin baik kualitas panitia pengadaan maka tingkat fraud atau kecurangan akan menurun. Hasil penelitian ini mendukung penelitian sebelumnya yang dilakukan oleh Yanavia (2014) dan Nisa Nurharjanti (2017) yang membuktikan bahwa kualitas panitia pengadaan berpengaruh negatif terhadap fraud pengadaan barang dan jasa.

Etika adalah norma-norma, kaidah-kaidah dan nilai-nilai moral yang berlaku. Dalam agency theory, principal menginginkan agar agen melakukan pekerjaannya dengan baik sesuai dengan kontrak kerja dan etika yang berlaku demi keuntungan institusi serta penerapan etika dalam pekerjaan merupakan hal yang penting bagi agen untuk melaksanakan pekerjaannya. Peraturan Bupati Badung No 40 tahun 2014 terdapat etika-etika pengadaan barang dan jasa di desa 
yaitu, bertanggung jawab, efisiensi anggaran dan penggunaan wewenang. Dari ketiga etika apabila ada salah satu yang tidak dilakukan, maka dapat dipastikan proses pengadaan barang dan jasa akan terhambat bahkan akan terjadi berbagai bentuk fraud (kecurangan).

Tabel 2. Hasil Uji Hipotesis

\begin{tabular}{lll}
\hline Variabel & T hitung & Sig uji t \\
\hline (Constant) & 7,943 & 0,000 \\
Kualitas Panitia Pengadaan & $-4,508$ & 0,000 \\
Etika Pengadaan & $-2,081$ & 0.042 \\
Kompensasi Panitia Pengadaan & $-0,078$ & 0,938 \\
Sistem dan Prosedur Pengadaan & $-2,278$ & 0,027 \\
Lingkungan Pengadaan & $-0,066$ & 0,948 \\
\hline
\end{tabular}

Sumber: Data Penelitian, 2019

Hipotesis kedua pada penelitian ini menyatakan bahwa etika pengadaan berpengaruh negatif terhadap fraud pengadaan barang dan jasa di Pemerintahan Desa. Hasil pengujian dengan menggunakan regresi linier berganda sejalan dengan hipotesis yang dirumuskan yang menunjukan bahwa etika pengadaan berpengaruh negatif terhadap fraud. Nilai regresi menunjukan nilai koefisien negatif sebesar 0,432 dengan nilai signifikansi sebesar 0,042 yang lebih kecil dari $\alpha=0,05(0,042<0,05)$. Hasil ini memiliki arti bahwa semakin baik dan beretika panitia pengadaan maka tingkat fraud atau kecurangan akan menurun. Hasil penelitian ini mendukung penelitian sebelumnya yang dilakukan oleh dan Hidayati et al., (2017) yang membuktikan bahwa etika pengadaan berpengaruh negatif terhadap fraud pengadaan barang dan jasa.

Kompensasi pengadaan barang dan jasa adalah salah satu faktor utama yang dapat memotivasi agen untuk melakukan pekerjaannya secara baik atau tidak baik dan faktor kompensasi panitia pengadaan dapat mendorong terjadinya fraud pengadaan Dalam organisasi, principal memiliki kewajiban untuk memberikan imbalan atas pekerjaan yang dilakukan oleh agen. Imbalan yang sesuai dengan kewajiban adalah hal yang paling dibutuhkan untuk mencegah terjadinya fraud. Hipotesis ketiga pada penelitian ini menyatakan bahwa kompensasi panitia pengadaan berpengaruh negatif terhadap fraud pengadaan barang dan jasa di Pemerintahan Desa. Hasil pengujian dengan menggunakan regresi linier berganda sejalan dengan hipotesis yang dirumuskan yang menunjukan bahwa etika pengadaan berpengaruh negatif terhadap fraud. Nilai regresi menunjukan nilai koefisien negatif sebesar 0,021 dengan nilai signifikansi sebesar 0,938 yang besar dari ${ }^{\alpha}=0,05(0,938>0,05)$. Hasil penelitian yang tidak signifikan dikarenakan responden tidak seluruhnya meyakini bahwa honor tambahan yang diterima pantia pengadaan telah sesuai dengan beban kerjanya, sehingga hasil ini memiliki arti bahwa kebijakan pemberian kompensasi tidak secara signifikan menurunkan kecenderungan terjadinya fraud. Hasil penelitian ini sejalan dengan Arifianti et al. (2016) dan Hidayati et al., (2017) yang membuktikan bahwa kompensasi panitia pengadaan tidak berpengaruh signifikan terhadap fraud pengadaan barang dan jasa.

Sistem dan prosedur pengadaan merupakan teknik dan cara yang harus dilakukan dalam proses pengadaan, agency theory berasumsi bahwa dalam 
organisasi principal memberikan kepercayaan kepada agen untuk melaksanakan pekerjaannya, dimana agen memiliki tugas dan kewenangan dalam proses pelaksanaan maupun perencanaan suatu pekerjaan yang diberikan oleh principal Dalam melaksanakan tugasnya, agen harus mengikuti prosedur yang ada agar pekerjaannya berjalan lancar dan dapat mencegah agar tidak terjadi kecurangan. Sistem dan prosedur pengadaan terdiri dari perencanaan, pelaksanaan dan pelaporan. Perencanaan yaitu langkah untuk, merencanakan hal apa yang dilakukan nanti, merencanakan barang apa yang akan dibeli. Pelaksanaan yaitu langkah implementasi atas apa yang telah direncanakan oleh panitia pengadaan. Pelaporan adalah langkah terakhir dalam pelaksanaan pengadaan, dimana semua hasil barang dan jasa yang diadakan (dibeli) dilaporkan, baik dalam bentuk berita acara maupun dalam bentuk surat.

Hipotesis keempat pada penelitian ini menyatakan bahwa sistem dan prosedur pengadaan berpengaruh negatif terhadap fraud pengadaan barang dan jasa di Pemerintahan Desa. Hasil pengujian dengan menggunakan regresi linier berganda sejalan dengan hipotesis yang dirumuskan yang menunjukan bahwa etika pengadaan berpengaruh negatif terhadap fraud. Nilai regresi menunjukan nilai koefisien negatif sebesar 0,506 dengan nilai signifikansi sebesar 0,027 yang lebih kecil dari ${ }^{\alpha}=0,05(0,042<0,05)$. Hasil ini memiliki arti bahwa semakin baik sistem dan prosedur pengadaan maka tingkat fraud atau kecurangan akan menurun. Hasil penelitian ini mendukung penelitian sebelumnya yang dilakukan oleh Astuti (2016), Hidayati et al., (2017) dan Nisa Nurharjanti (2017) dan yang membuktikan bahwa etika pengadaan berpengaruh negatif dan signifikan terhadap fraud pengadaan barang dan jasa.

Agency theory berasumsi bahwa adanya konflik antara principal dan agen salah satunya karena kepentingan yang saling bertentangan (conflict of interest) dan lingkungan kerja yang buruk dapat menyebabkan terjadinya fraud. Lingkungan pengadaan merupakan kondisi dimana pengadaan berlangsung, lingkungan dalam pengadaan barang dan jasa bisa dibedakan menjadi 2 yaitu lingkungan internal dan lingkungan eksternal. Lingkungan pengadaan barang dan jasa dibagi menjadi dua antara lain lingkungan dalam (internal) yaitu lingkungan tempat panitia bekerja dan lingkungan luar (eksternal) yaitu kerja sama antara pihak luar dalam pengadaan barang dan jasa (Yanavia, 2014).

Hipotesis kelima pada penelitian ini menyatakan bahwa lingkungan pengadaan berpengaruh negatif terhadap fraud pengadaan barang dan jasa di Pemerintahan Desa. Hasil pengujian dengan menggunakan regresi linier berganda sejalan dengan hipotesis yang dirumuskan yang menunjukan bahwa lingkungan pengadaan berpengaruh negatif terhadap fraud. Nilai regresi menunjukan nilai koefisien negatif sebesar 0,020 dengan nilai signifikansi sebesar 0,948 yang lebih besar dari ${ }^{\alpha}=0,05(0,948>0,05)$. Hasil penelitian yang tidak signifikan dikarenakan lingkungan pengadaan barang dan jasa yang ada belum mempunyai pengaruh dalam pencapaian tujuan. Hal ini bisa jadi dikarenakan tidak adanya supervisi dalam setiap tahapan proes pengadaan atau tidak adanya pre-audit (menetapkan rencana awal dari proses pengadaan) dimana beberapa responden menyatakan bahwa kerja sama antara panitia dan penyedia tidak terjalin dengan baik. Supervisi hanya dilakukan setelah pekerjaan selesai atau 
hanya dilakukan post-audit (evaluasi dilakukan setelah proses pengadaan selesai) saja. Kondisi ini menjadikan lingkungan pengadaan barang dan jasa tidak terkendali secara ideal, dan penelitian Nisa Nurharjanti (2017) menyatakan bahwa lingkungan pengadaan dipengaruhi oleh market environment dan legal environment, belum mempunyai pengaruh terhadap fraud pengadaan barang dan jasa. Hasil penelitian ini sejalan dengan Astuti (2016) dan Nisa Nurharjanti, (2017) yang membuktikan bahwa lingkungan pengadaan tidak berpengaruh signifikan terhadap fraud pengadaan barang dan jasa.

Penelitian ini menghasilkan simpulan mengenai pengaruh kualitas panitia pengadaan, etika pengadaan, kompensasi panitia pengadaan, sistem dan prosedur pengadaan serta lingkungan pengadaan terhadap fraud. Hasil uji dalam penelitian ini menemukan bahwa kualitas panitia pengadaan, etika pengadaan serta sistem dan prosedur pengadaan berpengaruh negatif terhadapp fraud pengadaan barang dan jasa. Penelitian ini mendukung agency theory yaitu kontrak kerja sama antara perangkat desa (agent) dengan masyarakat desa (principal) dalam pemerintahan desa, salah satunya perangkat desa (agen) melakukan pengadaan barang dan jasa yang transaparan sehingga masyarakat (principal) dapat mengetahuinya. Penelitian ini juga mendukung teori tentang pengadaan dan sistem pengadaan yang terdapat dalam Peraturan Kepala Lembaga Kebijakan Pengadaan Barang/Jasa di Desa Nomor 22 tahun 2015 dan Peraturan Bupati Badung Nomor 40 tahun 2014 dimana panitia pengadaan wajib mengetahui dan mentaati peraturan yang telah dibuat untuk menghindari terjadinya fraud (kecurangan) di Desa. Penelitian ini memberikan implikasi masukan bagi kepala dalam pengambilan keputusan terkait dengan pengadaan barang dan jasa di desa salah satunya dengan lebih mengawasi pelaksaan pengadaan barang dan jasa sehingga dapat mencegah kecenderungan fraud.

\section{SIMPULAN}

Kualitas panitia pengadaan berpengaruh negatif terhadap fraud pengadaan barang dan jasa di Pemerintah Desa di Kabupaten Badung, semakin baik kualitas panitia pengadaan maka tingkat fraud atau kecurangan semakin menurun. Etika pengadaan berpengaruh negatif terhadap fraud pengadaan barang dan jasa di Pemerintah Desa di Kabupaten Badung, semakin baik dan beretika panitia pengadaan maka tingkat fraud atau kecurangan semakin menurun. Kompensasi panitia pengadaan tidak berpengaruh terhadap fraud pengadaan barang dan jasa di Pemerintah Desa di Kabupaten Badung, dengan adanya kompensasi yang baik tidak secara signifikan dapat menurunkan tingkat fraud atau kecurangan. Sistem dan prosedur pengadaan berpengaruh negatif terhadap fraud pengadaan barang dan jasa di Pemerintah Desa di Kabupaten Badung, semakin baik sistem dan prosedur pengadaan maka tingkat fraud atau kecurangan semakin menurun. Lingkungan pengadaan tidak berpengaruh terhadap fraud pengadaan barang dan jasa di Pemerintah Desa di Kabupaten Badung, dengan adanya lingkungan pengadaan yang baik tidak secara signifikan dapat menurunkan tingkat fraud atau kecurangan.

Besarnya nilai Adjusted R Square dapat menjelaskan variabel terikat yang dapat dijelaskan hanya 41,8 persen, sedangkan sisnya 58,2 persen dijelaskan oleh variabel lainnya yang tidak dimasukan ke dalam penelitian ini. Penelitian 
selanjutnya disarankan untuk menggunakan atau menambahkan variabel bebas lain yang diduga dapat berpengaruh terhadap fraud pengadaan barang dan jasa. Penelitian ini tdak melibatkan responden dari penyedia barang/jasa. Sehingga, untuk penelitian mendatang disarankan sebaiknya melakukan sebuah penelitian dengan melibatkan pihak penyedia barang dan jasa agar dapat menemukan temuan dari persepsi yang berbeda.

\section{REFERENSI}

Abidin, M. Z. (2015). Tinjauan Atas Pelaksanaan Keuangan Desa dalam Mendukung Kebijakan Dana Desa. Jurnal Ekonomi \& Kebijakan Publik, 6(1), 61-76.

Adinda. (2015). Faktor Yang Mempengaruhi Terjadinya Kecurangan (Fraud) Di Sektor Pemerintahan Kabupaten Klaten. Accounting Analysis Journal, 4(3). https://doi.org/10.15294/aaj.v4i3.8311

Aini, N., Prayudi, M. A., \& Diatmika, P. G. (2017). Pengaruh Perspektif Fraud Diamond Terhadap Kecenderungan Terjadinya Kecurangan (Fraud) Dalam Pengelolaan Keuangan Desa (Studi Empiris Pada Desa Di Kabupaten Lombok Timur). E-Jurnal Akuntansi Universitas Pendidikan Ganesha, 8(2), 1-20. Retrieved from https://ejournal.undiksha.ac.id/index.php/S1ak/article/view/14583

Ambe, I. M., \& Badenhorst-Weiss, J. A. (2015). Procurement challenges in the South African public sector. Journal of Transport and Supply Chain Management, 6(1), 1. https://doi.org/10.4102/jtscm.v6i1.63

Anto, R. P., \& Amir, M. (2017). Competence of Village Apparatus In Management of Village Funds in North Konawe Regency-Indonesia. IOSR Journal of Businees an Management, 19(11), 1-20.

Arifianti, R., Santoso, B., \& Handajani, L. (2016). Perspektif Triangle Fraud Theory Dalam Pengadaan Barang/Jasa Di Pemerintah Provinsi Ntb. InFestasi, 11(2), 195. https:// doi.org/10.21107/infestasi.v11i2.1132

Astuti. (2016). Analisis Faktor-Faktor Yang Mempengaruhi Fraud Pengadaan Barang / Jasa Di Lingkungan Instansi. E Jurnal Akuntansi, 1-15.

Atmadja, A. T., \& Saputra, A. K. (2017). Pencegahan Fraud dalam Pengelolaan Keuangan Desa. Jurnal Ilmiah Akuntansi Dan Bisnis. https://doi.org/10.24843/jiab.2017.v12.i01.p02

Galih Prasetyo, A., \& Muis, A. (2015). Pengelolaan Keuangan Desa Pasca UU No. 6 Tahun 2014 Tentang Desa: Potensi Permasalahan dan Solusi. Jurnal Desentralisasi.

Gorsira, M., Steg, L., Denkers, A., \& Huisman, W. (2018). Corruption in Organizations: Ethical Climate and Individual Motives. Administrative Sciences, 8(1), 4. https:/ / doi.org/10.3390/admsci8010004

Hidayati, N., Mulyadi, J. M. V, \& Classsification, J. E. L. (2017). Faktor-Faktor Yang Mempengaruhi Fraud Dalam Kegiatan Pengadaan Barang dan Jasa. Journal Universitas Pancasila, (2), 275-294.

Ilham, I., Asmony, T., \& Handajani, L. (2017). the Governance of E-Procurement in Preventing Fraud Trends of Goods / Services Procurement: a Phenomenological Study. E-Proceeding Stie Mandala, 0(0), 1731-1752. 
Retrieved

from

http:/ / jurnal.stiemandala.ac.id/index.php/eproceeding/article/view/205

Li, T. M. (2016). Governing Rural Indonesia: Convergence on the Project System. $\begin{array}{llll}\text { Critical Policy } & \text { Studies, } & \text { 70(1), } & \text { 794. }\end{array}$ https://doi.org/https:// doi.org/10.1080/19460171.20 15.1098553.

Majumder, A., Ray, R., \& Sinha, K. (2016). A unified framework for the estimation of intra and inter country food purchasing power parities: India, Indonesia and Vietnam. Indian Growth and Development Review. https:// doi.org/10.1108/IGDR-09-2015-0039

Mazibuko, G., \& Fourie, D. (2017). Manifestation of unethical procurement practices in the South African public sector. African Journal of Public Affairs, 9(9), 106-117.

Meutia, I., \& Liliana. (2017). Pengelolaan Keuangan Dana Desa. Jurnal Akuntansi Multiparadigma. https:/ / doi.org/10.18202/jamal.2017.08.7058

Nisa Nurharjanti, N. (2017a). Faktor-Faktor yang Berhubungan dengan Fraud Pengadaan Barang/Jasa di Lembaga Publik. Jurnal Akuntansi Dan Investasi. https:// doi.org/10.18196/jai.180284

Nisa Nurharjanti, N. (2017b). Faktor-Faktor yang Berhubungan dengan Fraud Pengadaan Barang/Jasa di Lembaga Publik. Jurnal Akuntansi Dan Investasi, 18(2), 209-221. https:// doi.org/10.18196/jai.180284

Ogol, C. O., \& Moronge, M. (2017). Effects of ethical issues on procurement performance in public hospitals in kenya: a case of kenyatta national referral. The Strategic Journal of Business \& Change Management, 4(3), 787805.

Panda, B., \& Leepsa, N. M. (2017). Agency theory: Review of theory and evidence on problems and perspectives. Indian Journal of Corporate Governance, 1(1), 1-20. https://doi.org/https:/ / doi.org/10.1177/0974686217701467

Pepper, A., \& Gore, J. (2015). Behavioral Agency Theory: New Foundations for Theorizing About Executive Compensation. Journal of Management, 1(1), 112. https:/ / doi.org/https://doi.org/10.1177/0149206312461054

Pratama, Y. A., Amboningtyas, D., \& Yulianeu. (2017). The Influence of Good Corporate Governance and Financial Leverage to Profitability with Corporate Social Responbility as Intervening Variable (Case Study on Manufacturing Companies Listed on BEI Period 2012-2016). Journal of Managemen, 1(1), 1-12.

Roden, D. M., Cox, S. R., \& Kim, J. Y. (2016). The fraud triangle as a predictor of corporate fraud. Academy of Accounting and Financial Studies Journal, 1(1), 120.

Said, J., Alam, M. M., Ramli, M., \& Rafidi, M. (2017). Integrating ethical values into fraud triangle theory in assessing employee fraud: Evidence from the Malaysian banking industry. Journal of International Studies, 10(2), 170-184. https://doi.org/10.14254/2071-8330.2017/10-2/13

Santi Putri Laksmi, P., \& Sujana, I. K. (2019). Pengaruh Kompetensi SDM, Moralitas dan Sistem Pengendalian Internal Terhadap Pencegahan Fraud Dalam Pengelolaan Keuangan Desa. E-Jurnal Akuntansi. https://doi.org/10.24843/eja.2019.v26.i03.p18 
Sholihat, W., Nelly, R., \& Ratnawati, V. (2017). Analisis Pengelolaan Alokasi Dana Desa Di Kecamatan Seberida Kabupaten Indragiri Hulu. Jurnal Ekonomi.

Thorburn, C. C., \& Kull, C. A. (2015). Peatlands and Plantations in Sumatra, Indonesia: Complex Realities for Resource Governance, Rural Development and Climate Change Mitigation. Asia Pacific Viewpoint, 56(1), 153-168. https:// doi.org/http:// dx.doi.org/10.1111/apv.12045).

Tibuludji, R. (2017). Analisis Potensi Penyimpangan Dalam Pengadaan Barang/Jasa Pemerintah Terhadap Tindak Pidana Korupsi. Jaka - Jurnal Jurusan Akuntasi. https:/ / doi.org/10.32511/jaka.v1i1.82

Usuro, I., \& Adigwe, O. P. (2015). Budget Practices and the Nigerian Civil Service: New Insight From An Organisational Culture Perspektive Developing Country Studie. Accounting Analysis Journal, 1(1), 1-12.

Yanavia. (2014). Analisis Faktor-Faktor Yang Mendorong Terjadinya Fraud Pengadaan Barang/Jasa Pada Lingkungan Instansi Pemerintah Di Propinsi Sumatera Barat. Jurnal Eksplorasi Akuntansi.

Yunita, A., \& Christianingrum, C. (2019). Evaluasi Akuntabilitas Dan Efektivitas Pengelolaan Dana Desa Di Kabupaten Bangka Dan Kabupaten Belitung: Suatu Kajian Komprehensif. Tirtayasa Ekonomika. https:// doi.org/10.35448/jte.v14i1.5411

Zitha, H. E., \& Mathebula, N. E. (2015). Ethical Conduct of Procurement Officials and Implications on Service Delivery: A Case Study of Limpopo Provincial Treasury. Public and Municipal Finance, 4(3), 16-24. 